\title{
БІОГЕННІ ПОВЕРХНЕВО-АКТИВНІ РЕЧОВИНИ ЯК ПЕРСПЕКТИВНІ ЕКОЛОГІЧНО БЕЗПЕЧНІ ЗАСОБИ ДЛЯ ВИКОРИСТАННЯ В АГРОПРОМИСЛОВОСТІ ТА МЕДИЦИНІ
}

\author{
Поліш Н. В., Марінцова Н. Г.
}

\section{ВСТУП}

З огляду на надзвичайну потребу у високоефективних, безпечних та екологічних засобах поверхнево-активні речовини мікробного походження останнім часом вважаються тими перспективними сполуками, які завдяки своїй структурі та широкому спектру фізикохімічних i біологічних властивостей (здатності до зниження поверхневого натягу та емульгування різних субстратів, антимікробної, антиадгезивної активності) $€$ потенційно корисними у багатьох галузях промисловості, сільського господарства та медицини.

Як відомо 3 літературних джерел, біогенні поверхнево-активні речовини (біоПАР) мають здатність збільшувати проникність клітинних мембран та підсилювати дію інших речовин за сумісного використання, є низько токсичними, мають стабільні фізико-хімічні властивості та широкий діапазон $\mathrm{pH}$ і температури тощо. Вони $\epsilon$, на відміну від синтетичних ПАР, екологічно безпечними для довкілля, що також зумовлює велику зацікавленість ними дослідників.

Відомо, що біоПАР можна використовувати i як самостійні реагенти, і в комплексі з іншими біологічно активними сполуками для створення комплексних препаратів із покращеними функціональними характеристиками. Вони можуть використовуватися як для отримання нових, так і для вдосконалення наявних агропрепаратів, як фунгіциди, як консерванти у косметологічних засобах та медицині.

Завдяки широкому спектру біологічних властивостей, таких як антимікробні, фунгіцидні, противірусні, протипухлинні, антиадгезивні, емульгуючі, біоПАР мають перспективи для одержання нових ефективних лікарських та косметичних засобів. Одними 3 найважливіших представників поверхнево-активних речовин мікробного походження є сурфактин, який продукується бактерією Bacillus subtilis, та рамноліпіди, які синтезуються представниками роду Pseudomonas. Сурфактин проявляє широкий спектр біологічних активностей, таких як: антибактеріальна, противірусна, протигрибкова та гемолітична, оскільки здатний проникати в клітинні мембрани всіх 
видів бактерій. Спектр потенційного промислового застосування рамноліпідів включає підвищення нафтовидобутку, стабілізацію і дестабілізацію емульсій, очистку від нафтових забруднень води і грунтів, створення нових мийних засобів. За останні роки рамноліпіди були досліджені як потенційні терапевтичні засоби для лікування раку, псоріазу, як протимікробні засоби, а також як складові системи доставки ліків. Отже, сурфактин та рамноліпіди $\epsilon$ потужними препаратами-кандидатами для вирішення низки глобальних проблем медицини, промисловості та охорони навколишнього середовища.

Метою роботи $є$ аналіз даних літературних джерел щодо мікробного походження, хімічного складу, застосування та подальшої перспективи використання біогенних поверхнево-активних речовин у медицині.

\section{1. Структура та класифікація біогенних поверхнево-активних речовин (біоПАР)}

Відповідно до джерела їх мікробного походження, хімічного складу та молекулярної маси, біоПАР класифікують на такі основні класи: гліколіпіди, ліпопептиди, ліпопротеїни, жирні кислоти, фосфоліпіди і нейтральні ліпіди, полімерні поверхнево-активні речовини ${ }^{1}$. Ліпофільний фрагмент біоПАР зазвичай $є$ вуглеводневим ланцюгом або похідним жирних кислот, або білком (пептидом) із бічними гідрофобними ланцюгами, гідрофільний - пептидом, вуглеводом тощо 2 .

Найважливішою групою низькомолекулярних біоПАР є гліколіпіди, які містять моно- або олігосахариди, а також ліпідні фрагменти. Сахаридна частина - це глюкоза, маноза, галактоза, галактозосульфат, глюкуронова кислота, рамноза тощо. Ліпідна частина складається 3 насиченої або ненасиченої жирної кислоти, оксикислоти, жирного спирту. До важливих груп гліколіпідів належать рамноліпіди, софорозоліпіди і трегалозоліпіди ${ }^{3}$.

Рамноліпіди є основними гліколіпідами бактерій роду Pseudomonas. Вперше рамноліпіди були виявлені в супернатанті культуральної рідини

${ }^{1}$ Shekhar S., Sundaramanickam A., Balasubramanian T. Biosurfactant producing microbes and their potential applications: a review. Critical Reviews in Environmental Science and Technology. 2015. Vol. 45. № $14 . \quad$ P. 1522-1554. DOI: 10.1080/10643389.2014.955631.

${ }^{2}$ Nitschke M., Costa S.G., Contiero J. Structure and Applications of a Rhamnolipid Surfactant Produced in Soybean Oil Waste. Applied Biochemistry and Biotechnology. 2010. № 7. P. 2066-2074. DOI: 10.1007/s12010-009-8707-8.

${ }^{3}$ Petrikov K., Deleganb Y., Surinc A. Glycolipids of Pseudomonas and Rhodococcus oil-degrading bacteria used in bioremediation preparations: Formation and structure. Process Biochemistry. 2013. Vol. 48. № 5. P. 931-935. DOI: $10.1016 /$ j.procbio.2013.04.008. 
Pseudomonas pyocyanea С. Бергстром у 1946 році, а в кристалічному вигляді виділені Ф.Г. Джарвісом і М.Дж. Джонсоном у 1949 році $^{4}$. Бактерії роду Pseudomonas синтезують низку гомологічних рамноліпідів, у яких рамноза приєднана до жирнокислотного «хвосту» глікозидним зв'язком. Рамноліпіди різняться за кількістю $\beta$-гідрокси жирних кислот (1 або 2), кількістю одиниць рамнози (1 або 2), довжиною ланцюга i 14 насиченістю $\beta$-гідроксижирних кислот. Основними гомологами $\epsilon$ монорамноліпід (L-рамнозо- $\beta$-гідроксидеканоїл- $\beta$-гідроксидеканоат) і дирамноліпід (Lрамнозо-L-рамнозо- $\beta$-гідроксидеканоїл- $\beta$ гідроксидеканоат) $)^{5}$, P.aeruginosa синтезує всього понад двадцять гомологів у менших кількостях, найчастіше зустрічаються моно- та дирамноліпіди.

Рамноліпіди складаються з гідрофільної «голови», яка представлена однією або двома молекулами рамнози, і гідрофобного «хвоста» одного або двох ланцюгів жирних кислот, що визначає ії̈ поверхневоактивні властивості, такі як емульгування жирів та вуглеводнів, змочування різних поверхонь, зниження поверхневого і міжфазного натягу, підвищення проникності клітинних мембран ${ }^{6}$.

Іншим важливим класом гліколіпідів $є$ трегалозоліпіди, які синтезуюється бактеріями родів Mycobacterium, Arthrobacter i Rhodococcus, Gordonia та містять дисахарид трегалозу, який пов'язаний із так званими міколовими кислотами.

Софорозоліпіди складаються 3 дисахариду софорози, зв'язаного 3 довголанцюговими гідроксильованими жирними кислотами через глікозидний зв'язок. Синтезуються вони дріжджами, такими як Torulopsis bombicola, T. apicola, T.petrophilum, Candida lipolytica i Wickerhamiella domericqiae.

Маннозилеритроліпіди (MEL) - це гліколіпідні ПАР, які синтезуються дріжджами Candida antarctica i Candida sp SY 16 і складаються 3 цукру (манозилеритринол) та жирних кислот, компоненти яких визначені як капронова, додеканова, тетрадеканова, тетрадеценова кислоти.

${ }^{4}$ Jarvis F.G., Johnson M.J.. A glyco-lipide produced by Pseudomonas aeruginosa. Journal of the American Chemical Society. 1949. Vol. 71. № 12. P. 4124-4126. DOI: 10.1021/ja01180a073.

${ }^{5}$ Syldatk C., Lang S., Matulovic U., Wagner F. Production of Four Interfacial Active Rhamnolipids from /i-Alkanes or Glycerol by Resting Cells of Pseudomonas species DSM 2874. Zeitschrift für Naturforschung. 1985. № 1. P. 61-67.

${ }^{6}$ Chong H, Li Q. Microbial production of rhamnolipids: opportunities, challenges and strategies. Microbial cell factories. 2017. Vol. 16. № 1. P. 137. DOI: 10.1186/s12934017-0753-2. 
Мікробні ліпопептиди - це циклічні пептиди, ацильовані жирними кислотами. Вони продукуються такими мікроорганізмами, як Bacillus, Lactobacillus, Streptomyces, Pseudomonas i Serratia. Ліпопептиди здатні значно знижувати поверхневий натяг води, володіють антимікробною активністю. Найвідомішими представниками мікробних ліпопептидів $\epsilon$ сурфактин, поліміксин і антибіотик даптоміцин Streptomyces roseosporus тощо ${ }^{78}$.

Жирні кислоти. Деякі мікроорганізми, котрі $\epsilon$ деструкторами вуглеводнів, синтезують позаклітинні жирні кислоти під час вирощування на алканах і проявляють поверхнево-активні властивості. До жирних кислот біоПАР належать насичені жирні кислоти 3 довжиною ланцюга від $\mathrm{C}_{12}$ до $\mathrm{C}_{14}$ та складні жирні кислоти, що містять гідроксильні групи й алкільні бічні ланцюги. Показано, що Arthobactestrain AK-19 і P. aeruginosa 44T115 синтезували 40-80\% таких жирів, коли культивування проводили 3 використанням гексадекану та оливкової олії як джерела субстрату.

Різні види мікроорганізмів Acinetobacter, Arthrobacter, Pseudomonas, Halomonas, Bacillus i Candida, були зареєстровані для отримання полімерних біоПАР, які використовують для створення стабільних емульсій. Найбільш вивченими полімерними біоПАР $є$ емульсан i ліпозан. Раніше емульсан був відомий як один полімер, але М.П. Меркалді встановив що емульсан є комплексом, який приблизно на $80 \%$ (вага/вага) ліпополісахарид і 20\% (м/м) екзополісахарид 3 високою молекулярною масою9. Ліпозан $є$ ще одним ефективним емульгатором, який синтезується Candida lipolytica i здатний утворювати стабільні емульсії типу масла у воді 3 різними комерційними рослинними оліями. Структурні формули деяких найяскравіших представників біоПАР зображені у табл. 1.

${ }^{7}$ Banat I.M., Franzetti I., Gandol A. Microbial biosurfactants production, applications and future potential. Applied Microbiology and Biotechnology. 2010. Vol. 87. P. 427-444. DOI: 10.1007/s00253-010-2589-0.

${ }^{8}$ Soberón-Chávez, G., Maier, R.M. Biosurfactants: a general overview. Biosurfactants. 2011. Vol. 20. P 1-11. DOI: 10.1007/978 364214490.

9 Mercaldi M.P., DamsKozlowska H., Panilaitis B. Discovery of the dual polysaccharide composition of emulsan and the isolation of the emulsion stabilizing component. Biomacromolecules. 2008. Vol. 7. № 9. P. 1988-1996. DOI: 10.1021/bm800239p. 
Таблиця 1

Структурні формули біогенних поверхнево-активних речовин

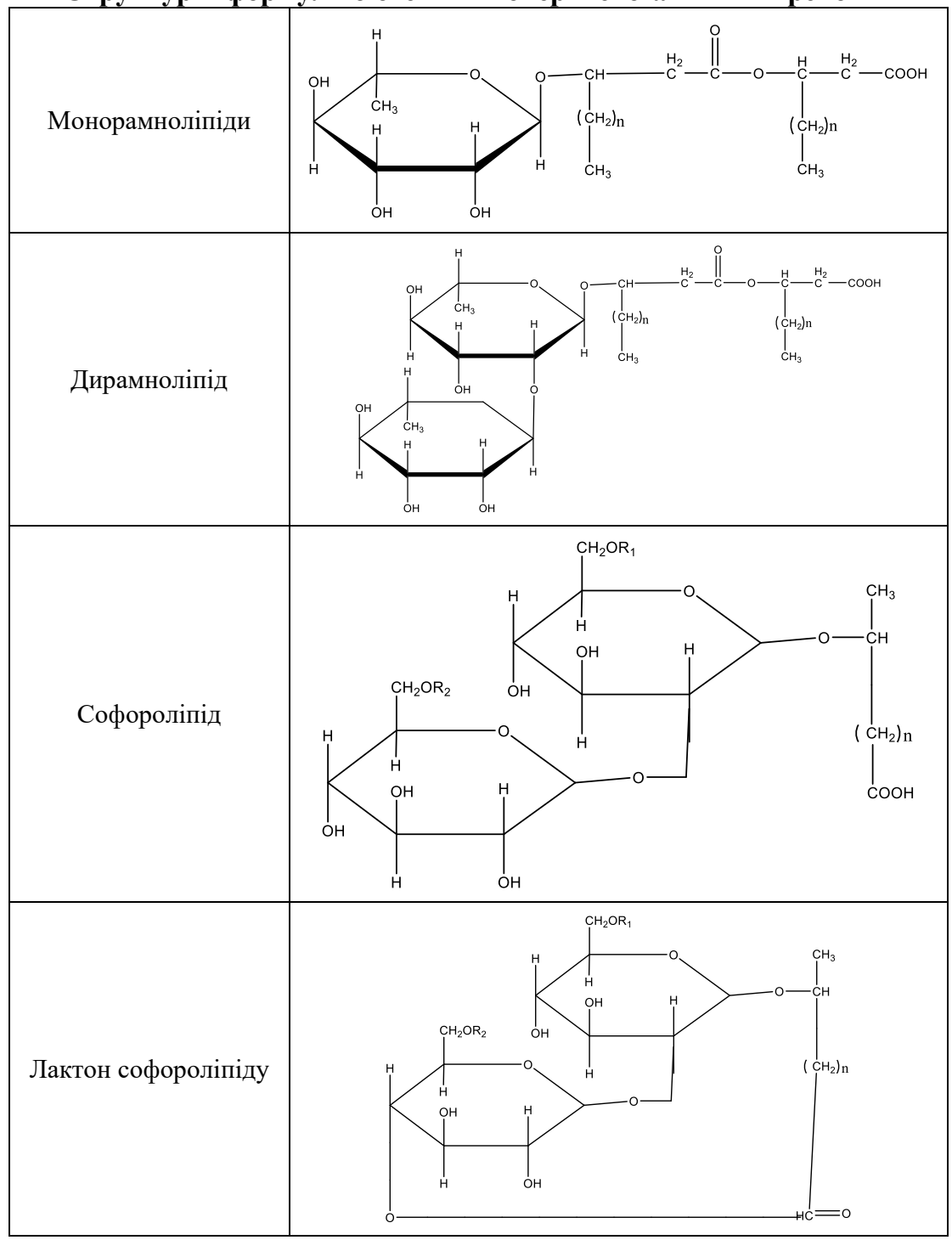


Продовження таблиці 1

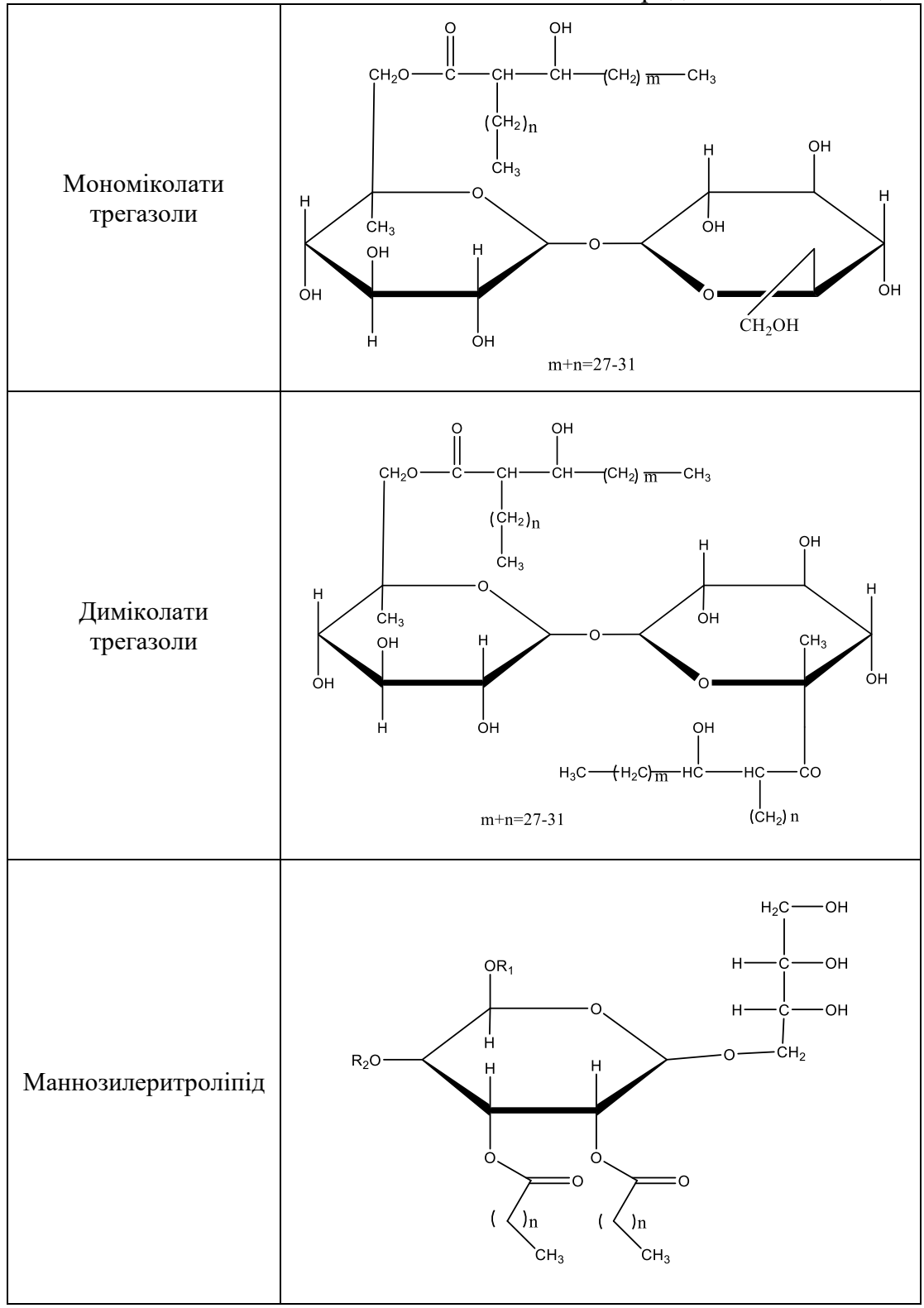




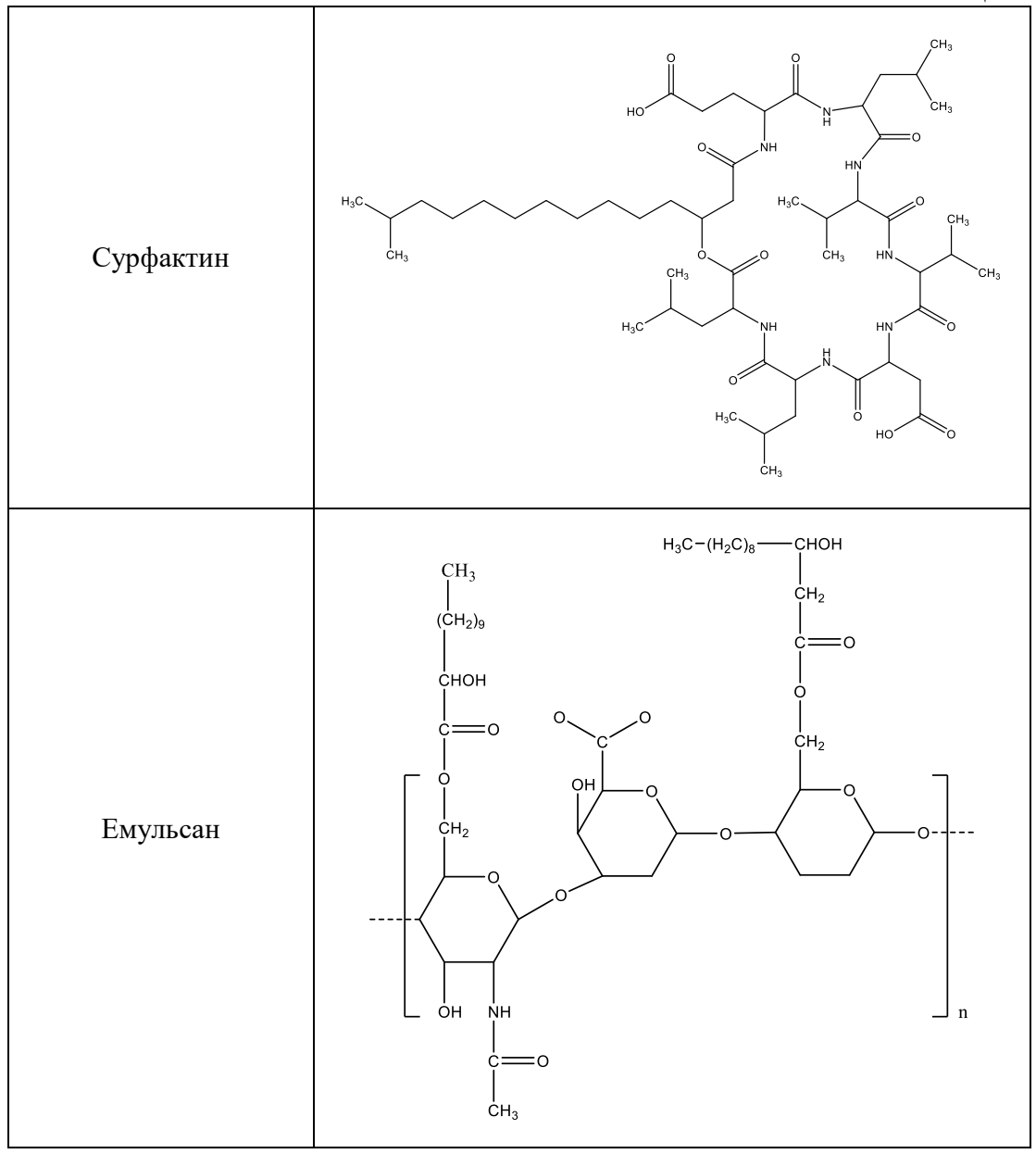

\section{2. Застосування біоПАР у сільському господарстві}

\section{1. Використання препаратів на основі біоПАР як біопестицидів}

Як відомо, хімічні добрива, пестициди та хімічні поверхнево-активні речовини в агрохімічних композиціях широко використовуються для знищення збудників хвороб рослин та підвищення родючості грунту. Проте вони мають негативний вплив на здоров'я людей та тварин, а також згубно впливають на навколишнє середовище. Їх залишки тривалий час можуть залишатися на посівах і накопичуватися в грунті і воді. Саме тому надзвичайно важливими завданнями сьогодення $\epsilon$ 
пошук та розроблення препаратів природного походження для заміни хімічних пестицидів. Нині на агропромисловому ринку відомі два біопестициди на основі біоПАР, які успішно склали конкуренцію хімічним попередникам. Першим є SERENADE компанії "AgraQuest Inc" (США), що є продуктом синтезу штаму Bacillus subtilis (штам QST 713), що виробляє більше 30 різних ліпопептидів, які працюють синергічно для захисту рослин від фітопатогенів. Список цільових рослин містить овочі, фрукти, горіхи, й виноград. Препарат може використовуватися проти таких захворювань, як сіра гниль, іржа, склеротинія, борошниста poca. Інший біопрепарат, який є на ринку на основі рамноліпіду, - Zonix, що є фунгіцидом компанії "Jeneil Biotech Inc" (США). Цільові рослини включають коріння, цибулинки плодових овочів, листових овочів, фруктових і горіхових дерев, цитрусові, тропічні культури (наприклад, бананові), ягідні, олійні, виноградні культури. Список патогенів, на які діє Zonix, містить Achlya, Albugo, Aphanomyces, Basidiophora, Olpidium, Pachymetra, Peronophthora, Peronosclerospora, Physoderma, Phytophthora, Plasmodiophora, Plasmopara, Polymyxa, Pseudoperonospora, Pythium, Rhizophydium, Sclerophthora, Sclerospora, Spongospora, Synchytrium i Trachysphaera. Антибактеріальні властивості біоПАР викликають інтерес для боротьби 3 хворобами рослин. Застосування супернатанта культуральних рідин, синтезованих бактеріями Pseudomonas fluorescences (6519E01), P. fluorescences biovar (6133D02), i Serratia plymuthica (6109D01), показало зменшення впливу фітопатогенів. Як відомо з літературних джерел, ще однією особливістю рамноліпідів є те, що вони можуть руйнувати мембрани зооспор і викликати лізис зооспор багатьох ооміцетів фітопатогенів грибів ${ }^{10}$.

\section{2. Використання біоПАР для виробництва агропрепаратів}

Завдяки своїм властивостям біоПАР можуть бути використані для створення агропрепаратів. Так, мікробні біоПАР можуть використовуватись як носії активних агентів у пестицидних, інсектицидних, i гербіцидних препаратах. Також $\epsilon$ дані про використання софорозоліпідів та їх похідних як ад’ювантів для пестицидів та гербіцидів під час використання біоПАР у агрокомпозиціях. БіоПАР можуть застосовуватися в сільському господарстві також як поживні речовини, розчинені в добривах, завдяки яким покращується засвоюваність рослинами поживних речовин. Встановлено, що застосування біоПАР у грунтах

${ }^{10}$ Stanghellini M.E., Miller R.M. Biosurfactants: their identity and potential efficacy in the biological control of zoosporic plant pathogens. Plant disease. 1997. Vol. 81. № 1. P. 4-12. DOI: 10.1094/PDIS.1997.81.1.4. 
сільськогосподарського призначення може сприяти деградації вуглеводнів, важких металів, пестицидів, покращуючи якість грунтів ${ }^{11}$. Варто відзначити азотфіксатор штаму Azotobacter beijreinckii, який $\epsilon$ продуцентом біоПАР і деструктором нафтових забруднень, а також має здатність до фіксування азоту, що сприяє родючості грунтів.

Перспективними препаратами у рослинництві $\epsilon$ природні фітогормони мікробного походження через простоту їх отримання, порівняну дешевизну та високу здатність їх до детоксикації в рослинному організмі, а також здатності легко зв'язуватися в клітині i катаболізувати. Крім того, за допомогою мікроорганізмів можна отримати фітогормональні препарати, які володіють більш високою біологічною активністю. Виділяють такі основні групи фітогормонів, як ауксини, гібереліни і цитокініни. Фітогормони, беручи участь у координації різних фізіологічних процесів у рослинах, регулюють стан спокою і проростання насіння, впливають на укорінення, цвітіння, розгалуження й дозрівання плодів. Вони підвищують резистентність рослин до факторів зовнішнього середовища, індукують або, навпаки, пригнічують експресії генів і синтез деяких ферментів, пігментів та метаболітів ${ }^{12}$.

\section{3. Перспективи застосування біоПАР у медицині}

Особливої уваги серед біоПАР заслуговує сурфактин, який виробляється грампозитивними бактеріями Bacillus subtilis та являє собою бактеріальний циклічний ліпопептид, котрий володіє великою поверхневою активністю. Завдяки своїм амфіфільним властивостям ця речовина може існувати як у гідрофільному, так і в гідрофобному середовищах. В ході різних досліджень властивостей сурфактину було виявлено, що він проявляє широкий спектр біологічної активності (антибактеріальна, противірусна, протигрибкова та гемолітична), оскільки здатний проникати в клітинні мембрани всіх видів бактерій ${ }^{13}$. Противірусна дія сурфактину відрізняє цей антибіотик від інших препаратів мікробного походження. Сурфактин розкладає не лише

11 Mani D., Kumar C. Biotechnological advances in bioremediation of heavy metals contaminated ecosystems: an overview with special reference to phytoremediation. International Journal of Environmental Science and Technology. 2014. No. 3. P. 843-872. DOI: $10.1007 / \mathrm{s} 13762-013-0299-8$.

${ }^{12}$ Reguera M., Peleg Z., Abdel-Tawab Y.M. Stress-induced cytokinin synthesis increases drought tolerance through the coordinated regulation of carbon and nitrogen assimilation in rice. Plant Physiology. 2013. Vol. 163. № 4. P. 1609-1622.

${ }^{13}$ Borriss R., Danchin A., Harwood C.R., Médigue C., Rocha E.P., Sekowska A., Vallenet D. Bacillus subtilis, the model Gram-positive bacterium: 20 years of annotation refinement. Microbial biotechnology. 2018. Vol. 1. № 11. P. 3-17. DOI: 10.1111/17517915.13043 . 
вірусний ліпід, що обволікається, але й капсид вірусу через утворення іонних каналів. Цей процес був доведений шляхом тестування на декілька вірусів, таких як ВІЛ (вірус імунодефіциту) та вірус простого герпесу. Крім того, ізоформи ланцюга жирних кислот, що містять 14 або 15 атомів вуглецю, виявили покращення у вірусі, а ті, що проникли в клітину, не зазнали впливу. На жаль, за високих концентрацій білка або ліпідів противірусна активність сурфактину була невелика. Основним недоліком сурфактину є його неспецифічна цитотоксичність, яка спостерігалась за високих концентрацій приблизно від 40 мкМ до 60 мкМ. За концентрацій нижче 25 мкМ токсичний ефект сурфактину незначний. Відомо, що сурфактин діє на широкий діапазон вірусів, зокрема вірус збудника лихоманки, вірус звичайного герпесу (HSV), віруси герпесу свиней, везикулярного стоматиту, вірус імунодефіциту мавп, вірус кальцивірозу кишок та енцефаломіокардиту мишей. Аналог сурфактину - пумілацидин проявляє антивірусну дію щодо звичайного вірусу герпесу 1 (HSV-1). Механізм противірусної дії вивчений лише для сурфактину. Показано, що цей ліпопептид $є$ ефективнішим проти вірусів, що мають оболонку (ретровіруси, віруси герпесу), ніж проти безоболонкових вірусів. Таке явище зумовлено саме тим, що механізм дії біоПАР пов'язаний зі взаємодією його молекул із зовнішньою оболонкою вірусів та утворенням у ній каналів із подальшою дезінтеграцією ${ }^{14,15}$.

Мікоплазми є серйозними збудниками захворювань як людини, так i тварин, таких як гостре запалення дихальних шляхів (включаючи пневмонію), інфекції сечостатевих шляхів та СНІД. Лікування антибіотиками $\epsilon$ найефективнішою процедурою для усунення або придушення мікоплазмової інфекції в культурах клітин. Сурфактин використовується для лікування клітинних культур та очищення біотехнологічних продуктів від забруднення мікоплазмою. Загалом антибіотикотерапія має тривалий успішний спосіб знезараження і не виявляє небажаних побічних ефектів та цитотоксичних ефектів на клітини еукаріотів. Сурфактини мають різнобічні біоактивні властивості зі значною антимікоплазмовою активністю. Їх розпад, очевидно, зумовлений фізико-хімічною взаємодією мембранноактивного сурфактину із зовнішньою частиною ліпідного мембранного шару, що спричиняє зміни проникності, а за більш високих

${ }^{14}$ Peypoux F., Bonmatin J.M., Wallach J. Recent trends in the biochemistry of surfactin. Applied Microbiology and Biotechnology. 1999. Vol. 51. № 5. P. 553-563. DOI: 10/1007/s002530051432.

15 Joshi S., Bharucha C., Desai A. J. Production of biosurfactant and antifungal compound by fermented food isolate Bacillus subtilis 20B. Bioresource technology. 2008. Vol. 99. № 11. P. 4603-4608. DOI: 10.1016/j.biortech.2007.07.030. 
концентрацій приводить до дезінтеграції мембранної системи мікоплазми завдяки їі поверхневій активності.

Відомі деякі лікарські препарати (антибіотики, фунгіциди, гемолітичні та антимікробні речовини) мікробного походження, які вже давно успішно використовуються в медичній практиці. Наприклад, антибіотик граміцидин $\mathrm{C}$, який продукується Bacillus brevis ${ }^{16}$ та застосовується під час лікування гнійних і запальних інфекцій шкіри і м'яких тканин, виразок, пролежнів, за запальних захворювань вуха, горла, стоматиту, гінгівіту, кон'юнктивіту, кератиту, остеомієліту (запалення кісткового мозку і прилеглої кісткової тканини), блефариту, опіках шкіри тощо.

Поліпептидний антибіотик поліміксин В, продукований Paenibacillus polymyxa, використовується для лікування інфекційно-запальних захворювань шлунково-кишкового тракту, менінгіту, пневмонії, захворювань сечових шляхів (цистит, уретрит), ЛОР-органів (отит, синусит, гайморит), шкіри (інфіковані опіки, абсцес, флегмона, пролежні тощо), кісток (остеомієліт), очей (кон'юнктивіт, кератит) тощо ${ }^{17}$. Ліхенізин, пумілацидин антимікробні ліпопептиди, що продукуються B. Licheniformis та Bacillus pumilus, відповідно, пригнічують ріст патогенних мікроорганізмів у шлунково-кишковому тракті.

Циклоспорин уперше виділений у 1969 році 3 продуктів життєдіяльності грибка Tolypocladium inflatum у Норвегії Гансом Петером Фреєм. Циклоспорин - циклічний поліпептид, до складу якого входять 11 амінокислот. Це сильнодіючий імуносупресивний ЛЗ, що пригнічує розвиток клітинно-опосередкованих реакцій, включаючи імунітет відносно алотрансплантату, шкірну чутливість уповільненого типу, експериментальний алергічний енцефаломієліт, артрит, зумовлений ад’ювантом Фрейнда, хворобу «трансплантат проти хазяїна» і залежне від Т-лімфоцитів утворення антитіл; пригнічує утворення і вивільнення лімфокінів, включаючи інтерлейкін 2 (фактор росту Т-лімфоцитів); блокує лімфоцити у стані спокою у фазі G0 або G1 клітинного циклу i пригнічує антиген, залежне вивільнення лімфокінів активованими Т-лімфоцитами; діє на лімфоцити специфічно

${ }^{16}$ Haddad N.I., Wang J., Mu B. Isolation and characterization of a biosurfactant producing strain, Brevibacilis brevis HOB1. Journal of industrial microbiology \& biotechnology. 2008. Vol. 35. № 12. P. 1597-1604. DOI: 10.1007/s 10295-008-0403-0.

${ }^{17}$ Falagas M.E., Grammatikos A.P., Michalopoulos A. Potential of old-generation antibiotics to address current need for new antibiotics. Expert review of anti-infective therapy. 2008. Vol. 6. № 5. P. 593-600. DOI: 10.1586/14787210.6.5.593. 
й оборотно; на відміну від цитостатиків, не пригнічує гемопоез і не впливає на функцію фагоцитів ${ }^{18}$.

Даптоміцин - це природний антибіотик із групи ліпопептидів, виділений із Streptomyces roseosporus, обмеженого спектру дії. Торговою назвою $є$ кубіцин. Препарат має бактерицидну дію, що обумовлена його зв'язуванням 3 мембранами бактерій та швидкою деполяризацією мембранного потенціалу клітин, внаслідок чого наступає інгібування синтезу білків, ДНК і РНК, а також загибель бактерій, що не супроводжується руйнуванням клітин бактерій. До даптоміцину чутливі виключно грампозитивні бактерії, такі як стафілококи, у тому числі резистентні до метициліну, ванкоміцину, лінезоліду; стрептококи; клостридії; пептостептококи. Грамнегативні бактерії нечутливі до даптоміцину. Даптоміцин переважно застосовують під час сепсису, який спричинює Staphylococcus aureus (включаючи бактеріальний ендокардит), та ускладнених інфекціях шкіри та м'яких тканин ${ }^{19}$.

Нині рамноліпіди практично не мають застосування в медицині, але $\epsilon$ позитивні результати, отримані у різних лабораторіях світу, які дають підстави розглядати їх як перспективні екологічні, безпечні та ефективні лікарські засоби завдяки широкому спектру їх біологічних властивостей, а саме антимікробної, противірусної та антиадгезивної дії. Рамноліпіди, які сильно поширені у природі, синтезуються представниками роду Pseudomonas та мають здатність засвоювати найрізноманітніші за природою субстрати і рости в різних екологічних умовах. Для їх росту придатні різні середовища: від води очищеної 3 мінімальним вмістом солей до складних середовищ, що включають речовини тваринного й рослинного походження та похідні нафти. Як відомо, перша згадка про рамноліпіди з'явилася ще у 40-х роках XX ст. Сьогодні близько 60 гомологів рамноліпідів синтезуються представниками роду Pseudomonas, серед яких найкраще вивченими $є$ штами Pseudomonas aeruginosa. Спектр потенційного промислового застосування рамноліпідів включає підвищення нафтовидобутку, стабілізацію і дестабілізацію емульсій; очистку від нафтових

${ }^{18}$ Palmeiro B.S. Cyclosporine in veterinary dermatology. Veterenary Clinic of North America: Small Animal Practice. 2013. Vol. 43, № 1. P. 153-171. DOI: 10.1016/j.cvsm.2012.09.00.

19 Gudiña E.J., Rangarajan V., Sen R., Rodrigues L.R. Potential therapeutic applications of biosurfactants. Trends in pharmacological sciences. 2013. Vol. 34. № 12. P. 667-675. DOI: 10.1016/j.tips.2013.10.002. 
забруднень води і грунтів, створення нових мийних засобів ${ }^{20}$. За останні роки рамноліпіди були досліджені як потенційні терапевтичні засоби для лікування раку, псоріазу, як протимікробні засоби, а також як складові системи доставки ліків, що дало поштовх для відкриття нових напрямів для створення та дослідження нових комплексних препаратів на основі рамноліпідів.

Так, для рамноліпідів було доведено протимікробну дію, антифітовірусний ефект та зооспорицидну активність. Також збільшується інтерес науковців до впливу рамноліпідів на клітинні лінії людини та тварин.

Такі властивості рамноліпідів, як стимуляція утворення іонних каналів та підвищення електропровідності в ліпідних мембранах, вплив на АТФазу, посилення імунної відповіді, дають можливість використання їх у біології для вивчення будови і функції біліпідних мембран, адаптивних механізмів та енергетичних процесів у клітинах, імунологічних реакцій, а також у лабораторній практиці під час створення гібридів.

Досліджено, що рамноліпіди впливають на культури фібробластів. Зовсім недавно властивості, що нагадують ендотоксин, були описані для рамноліпідів. Рамноліпіди також аналізували під час лікування псоріазу i в процесі шкірного загоєння ран. Попри важливість біологічного механізму дії взаємодії рамноліпідів із мембраною, дуже мало відомо стосовно молекулярної взаємодії рамноліпідів із фосфоліпідами. Оскільки рамноліпіди отримують як суміш гомологів 3 різною довжиною алкільного ланцюга, то зрозуміло, що розмір гідрофільних груп може впливати на їх властивості. Важливо з'ясувати внесок кожного індивідуального гомологічного рамноліпіду на біологічну активність, щоби зрозуміти їх механізм дії та одержання рамноліпідного продукту з бажаними властивостями для конкретного використання ${ }^{21,22}$.

Згідно з даними ВООЗ, рак молочної залози $є$ однією $з$ основних причин смерті у світі. Це обумовлює сучасні провідні біотехнологічні та

${ }^{20}$ Banat I.M., Makkar R.S., Cameotra S.S. Potential commercial applications of microbial surfactants. Applied microbiology and biotechnology. 2000. Vol. 53. № 5. P. 495-508. DOI: $10.1007 / \mathrm{s} 002530051648$.

21 Abalos A., Pinazo A., Infante M R., Casals M., Garcia F., Manresa A. Physicochemical and antimicrobial properties of new rhamnolipids produced by Pseudomonas a eruginosa AT10 from soybean oil refinery wastes. Langmuir. 2001. Vol. 17. № 5. P. 1367-1371. DOI: 10.1021/la0011735.

${ }^{22}$ Duarte C., Gudiña E.J., Lima C.F., Rodrigues L.R. Effects of biosurfactants on the viability and proliferation of human breast cancer cells. AMB Express. 2014. Vol. 4. № 1 (40). DOI: 10.1186/s13568-014-0040-0. 
світові фармацевтичні компанії, що виробляють основну масу препаратів, спрямованих на боротьбу з цим захворюванням, розробляти та вдосконалювати нові методи лікування цього захворювання. Дослідження показали, що рамноліпіди можуть діяти як протипухлинні сполуки, що перешкоджають прогресуванню деяких форм раку. Проведено попередні дослідження цитотоксичної активності рамноліпідів щодо ракових клітинних ліній, у тому числі на клітинах раку молочної залози людини MCF-7 ${ }^{23}$. Наприклад, інгібуючу дію двох дирамноліпідів, продукованих Pseudomonas aeruginosa B189, досліджували на клітинах MCF-7 методом серійних розведень. Доведено, що дирамноліпід (RhaRha- $\mathrm{C}_{10}-\mathrm{C}_{10}$ ) при MIC (мінімальній інгібуючій концентрації) 6,25 мкг/мл може пригнічувати проліферацію пухлинних клітин MCF-7, а дирамноліпід (Rha-Rha- $\mathrm{C}_{10}-\mathrm{C}_{12}$ ) при цій концентрації не виявляв протипухлинного ефекту. Дирамноліпідний гомолог Rha-Rha$\mathrm{C}_{10}-\mathrm{C}_{10}$ від P. aeruginosa M14808 демонстрував більш високе пригнічення росту клітин та більш високу індукцію апоптозу в раковій клітинній лінії MCF-7 порівняно з аналогічним гомологом P. aeruginosa B189 ${ }^{24,25}$. Отже, зважаючи на вищезазначене, відносимо рамноліпіди до перспективних засобів для лікування раку молочної залози.

Існують дані про те, що проводяться дослідження рамноліпідів як потенційних засобів для лікування захворювань ясен та регенерації пародонту, лікування виразки тощо. $Є$ дані, що рамноліпіди були ефективними при загоюванні ран та під час лікування променевих опіків, лікування зморшок та ознак старіння, в нанотехнології для рецептури мікроемульсії та синтезу наночастинок, а також як системи доставки ліків.

Однак висока вартість виробництва порівняно із синтетичними ПАР значною мірою перешкоджає їх широкому застосуванню. Як наслідок, теперішні дослідження науковців зосереджені значною мірою на визначенні можливих шляхів зниження витрат на виробництво

${ }^{23}$ Jiang L., Shen C., Long X., Zhang G., Meng, Q. Rhamnolipids elicit the same cytotoxic sensitivity between cancer cell and normal cell by reducing surface tension of culture medium. Applied Microbiology and Biotechnology. 2014. Vol. 98. № 24, P. 10187-10196. DOI: 10.1007/s00253-014-6065-0.

${ }^{24}$ Rahimi K., Lotfabad T.B., Jabeen F., Ganji S.M. Cytotoxic effects of mono-and dirhamnolipids from Pseudomonas aeruginosa MR01 on MCF-7 human breast cancer cells. Colloids and Surfaces B: Biointerfaces. 2019. Vol. 181. P. 943-952. DOI: 10.1016/j.colsurfb.2019.06.058.

${ }^{25}$ Christova N., Tuleva B., Kril A. Chemical Structure and In Vitro Antitumor Activity of Rhamnolipids from Pseudomonas aeruginosa BN10. Applied Biochemistry and Biotechnology. 2013. Vol. 170. P. 676-689. DOI: 10.1007/s12010-013-0225-z. 
рамноліпідів, включаючи використання дешевих субстратів, ідентифікацію штамів 3 високою виробничою потужністю.

\section{ВИСНОВКИ}

Біологічна активність, стійкість у широких діапазонах температури, $\mathrm{pH}$, висока ефективність, біодеградабельність та низька токсичність біогенних поверхнево-активних речовин привели до широкого спектру їх застосувань у галузі медицини та сільського господарства. Вони корисні як антибактеріальні, протигрибкові та противірусні засоби, а також мають потенціал для подальших досліджень як протиракові препарати та складові системи доставки ліків. БіоПАР можуть бути використані як самостійні реагенти, а також для створення комплексних препаратів із покращеними функціональними характеристиками. $\mathcal{C}$ кілька перспективних напрямів для застосування біоПАР у аргопромисловості, таких як покращення якості грунту, біоконтроль фітопатогенів, імуностимулюючий вплив на рослини та заміна синтетичних ПАР біогенними під час виробництва агропрепаратів (зокрема, пестицидів).

Базуючись на результатах проведеного дослідження та провівши аналіз літературних даних щодо одержання біогенних поверхневоактивних речовин, основних аспектів їх використання у медицині та сільському господарстві, доходимо висновку, що рамноліпіди та сурфактин мають великий потенціал для подальших досліджень і дають підстави розглядати їх як перспективні екологічні, безпечні та ефективні лікарські засоби. Незважаючи на те, що вони є відносно новим продуктом сучасної біотехнології, їхню роль як безпечних екологічних засобів важко переоцінити.

\section{АНОТАЦІЯ}

БіоПАР - це структурно різноманітна група поверхнево активних речовин, що синтезуються мікроорганізмами та володіють унікальними фізико-хімічними властивостями, що робить їх цікавими для досліджень.

В огляді проаналізовано літературні дані щодо характеристики, хімічного складу поверхнево активних речовин мікробного походження та спектру їх застосування в медицині, промисловості та сільському господарстві. Встановлено доцільність проведення подальших досліджень рамноліпідів як антибактеріальних, протигрибкових, противірусних та протиракових препаратів.

Результати роботи свідчать про доцільність та перспективи використання рамноліпідів як складових системи доставки ліків. БіоПАР, на відміну від синтетичних поверхнево активних сполук, 
$\epsilon$ екологічно безпечними, біодеградабельними й низькотоксичними, тому можуть стати альтернативними засобами в багатьох галузях.

\section{ЛITЕРАТУРA}

1. Shekhar S., Sundaramanickam A., Balasubramanian T. Biosurfactant producing microbes and their potential applications: a review. Critical Reviews in Environmental Science and Technology. 2015. Vol.45. № 14. P. 1522-1554. DOI: 10.1080/10643389.2014.955631.

2. Nitschke M., Costa S. G., Contiero J. Structure and Applications of a Rhamnolipid Surfactant Produced in Soybean Oil Waste. Applied Biochemistry and Biotechnology. 2010. № 7. P. 2066-2074. DOI: 10.1007/s12010-009-8707-8.

3. Petrikov K., Deleganb Y., Surinc A. Glycolipids of Pseudomonas and Rhodococcus oil-degrading bacteria used in bioremediation preparations. Formation and structure. Process Biochemistry. 2013. Vol. 48. № 5. P. 931-935. DOI: 10.1016/j.procbio.2013.04.008.

4. Jarvis F.G., Johnson M.J. A glyco-lipide produced by Pseudomonas aeruginosa. Journal of the American Chemical Society. 1949. Vol. 71. № 12. P. 4124-4126. DOI: 10.1021/ja01180a073.

5. Syldatk C., Lang S., Matulovic U., Wagner F. Production of Four Interfacial Active Rhamnolipids from i-Alkanes or Glycerol by Resting Cells of Pseudomonas species DSM 2874. Zeitschrift für Naturforschung. 1985. № 1. P. 61-67.

6. Chong H., Li Q. Microbial production of rhamnolipids: opportunities, challenges and strategies. Microbial cell factories. 2017. Vol. 16. № 1. P. 137. DOI: 10.1186/s12934-017-0753-2.

7. Banat I.M., Franzetti I., Gandol A. Microbial biosurfactants production, applications and future potential. Applied Microbiology and Biotechnology. 2010. Vol. 87. P. 427-444. DOI: 10.1007/s00253-010-2589-0.

8. Soberón-Chávez G., Maier R.M. Biosurfactants: a general overview. Biosurfactants. 2011. Vol. 20. P. 1-11. DOI: 10.1007/978 3642144905.

9. Mercaldi M.P., DamsKozlowska H., Panilaitis B. Discovery of the dual polysaccharide composition of emulsan and the isolation of the emulsion stabilizing component. Biomacromolecules. 2008. Vol. 7. № 9. P. 1988-1996. DOI: 10.1021/bm800239p.

10. Stanghellini M.E., Miller R.M. Biosurfactants: their identity and potential efficacy in the biological control of zoosporic plant pathogens. Plant disease. 1997. Vol. 81. № 1. P. 4-12. DOI: 10.1094/PDIS.1997.81.1.4.

11. Mani D., Kumar C. Biotechnological advances in bioremediation of heavy metals contaminated ecosystems: an overview with special reference to phytoremediation. International Journal of Environmental Science and Technology. 2014. No. 3. P. 843-872. DOI: 10.1007/s13762-013-0299-8. 
12. Reguera M., Peleg Z., Abdel-Tawab Y. M. Stress-induced cytokinin synthesis increases drought tolerance through the coordinated regulation of carbon and nitrogen assimilation in rice. Plant Physiology. 2013. Vol. 163. № 4. P. 1609-1622.

13. Borriss R., Danchin A., Harwood C. R., Médigue C., Rocha E. P., Sekowska A., Vallenet D. Bacillus subtilis, the model Gram-positive bacterium: 20 years of annotation refinement. Microbial biotechnology. 2018. Vol. 1. № 11. P. 3-17. DOI: 10.1111/1751-7915.13043.

14. Peypoux F, Bonmatin J.M., Wallach J., Recent trends in the biochemistry of surfactin. Applied Microbiology and Biotechnology. 1999. Vol. 51. № 5. P. 553-63. DOI: 10/1007/s002530051432.

15. Joshi S., Bharucha C., Desai A.J. Production of biosurfactant and antifungal compound by fermented food isolate Bacillus subtilis $20 \mathrm{~B}$. Bioresource technology. 2008. Vol. 99. № 11. P. 4603-4608. DOI: 10.1016/j.biortech.2007.07.030.

16. Haddad N.I., Wang J., Mu B. Isolation and characterization of a biosurfactant producing strain, Brevibacilis brevis HOB1. Journal of industrial microbiology \& biotechnology. 2008. Vol. 35. № 12. P. 15971604. DOI: 10.1007/s10295-008-0403-0.

17. Falagas M.E., Grammatikos A.P., Michalopoulos A. Potential of oldgeneration antibiotics to address current need for new antibiotics. Expert review of anti-infective therapy. 2008. Vol. 6. № 5. P. 593-600. DOI: 10.1586/14787210.6.5.593.

18. Palmeiro B.S. Cyclosporine in veterinary dermatology. Veterenary Clinic of North America: Small Animal Practice. 2013. Vol. 43. № 1. P. 153-171. DOI: 10.1016/j.cvsm.2012.09.00.

19. Gudiña E.J., Rangarajan V., Sen R., Rodrigues L. R. Potential therapeutic applications of biosurfactants. Trends in pharmacological sciences. 2013. Vol. 34. № 12. P. 667-675. DOI: 10.1016/j.tips.2013.10.002.

20. Banat I.M., Makkar R.S., Cameotra S.S. Potential commercial applications of microbial surfactants. Applied microbiology and biotechnology. 2000. Vol. 53. № 5. P. 495-508. DOI: $10.1007 / \mathrm{s} 002530051648$.

21. Abalos A., Pinazo A., Infante M.R., Casals M., Garcia F., Manresa A. Physicochemical and antimicrobial properties of new rhamnolipids produced by Pseudomonas a eruginosa AT10 from soybean oil refinery wastes. Langmuir. 2001. Vol. 17. № 5. P. 1367-1371. DOI: 10.1021/la0011735.

22. Duarte C., Gudiña E.J., Lima C.F., Rodrigues L.R. Effects of biosurfactants on the viability and proliferation of human breast cancer cells. AMB Express. 2014. Vol. 4. № 1 (40). DOI: 10.1186/s13568-014-0040-0.

23. Jiang L., Shen C., Long X., Zhang G., Meng Q. Rhamnolipids elicit the same cytotoxic sensitivity between cancer cell and normal cell by 
reducing surface tension of culture medium. Applied Microbiology and Biotechnology. 2014. Vol. 98. № 24. P. 10187-10196. DOI: 10.1007/s00253-014-6065-0.

24. Rahimi K., Lotfabad T.B., Jabeen F., Ganji S.M. Cytotoxic effects of mono-and di-rhamnolipids from Pseudomonas aeruginosa MR01 on MCF-7 human breast cancer cells. Colloids and Surfaces B: Biointerfaces. 2019. Vol. 181. P. 943-952. DOI: 10.1016/j.colsurfb.2019.06.058.

25. Christova N., Tuleva B., Kril A. Chemical Structure and In Vitro Antitumor Activity of Rhamnolipids from Pseudomonas aeruginosa BN10. Applied Biochemistry and Biotechnology. 2013. Vol. 170. P. 676-689. DOI: 10.1007/s12010-013-0225-z.

Information about the authors: Polish N. V., PhD Student at the Department of Technology Biologically Active Substances, Pharmacy and Biotechnology Lviv Polytechnic National University 12, S. Bandery str., Lviv, 79013, Ukraine

Marintsova N. H.,
Candidate of Chemical Sciences,
Associate Professor at the Department of Technology Biologically Active
Substances, Pharmacy and Biotechnology
Lviv Polytechnic National University
12, S. Bandery str., Lviv, 79013, Ukraine

